\begin{abstract}
20 Hayati Bilgiç'

\section{Özet}

Sarkoidoz, kronik seyirli, multisistemik olabilen granulomlarla seyreden bir hastalıktır. Her organ ve dokuda sarkoidoz tutulumu gösterilmiştir. Granülamatöz bir hastalık olmasından dolayı da tanı sırasında diğer granülamatöz inflamasyonla seyreden birçok hastalıkla karışabilmektedir. Olgumuzda olduğu gibi memede kitle ile kendini gösteren sarkoidoz hastalığında öncelikle malignite düşünülerek gerekli tetkikler yapılmıştır. Meme ve akciğer sarkoidozu olan olgu literatürler eşliğinde sunuldu.
\end{abstract}

Memede Kitle ile Başvuran Hastada Meme ve Akciğer Sarkoidozu Birlikteliği

\title{
Sarcoidosis of the Breast and Lung Association Presenting with Breast Mass
}

Cantürk Taşçı, Sait Yeşillik, ${ }^{2}$ Armağan Günal,, ${ }^{3}$ Sedat Yılmaz,, Bülent Karaman, Ergun Tozkoparan,

Anahtar Sözcükler: Meme sarkoidozu, akciğer sarkoidozu, granülamatöz inflamasyon.

\section{Abstract}

Sarcoidosis is a chronic, multisystemic disease that can be characterized by granulomas. Each organ and tissue involvement of sarcoidosis is shown. A granulomatous disease due to the disease at diagnosis may be confused with other granulomatous inflammation. The form of presentation of sarcoidosis can be many. Sarcoidosis patients presenting with a breast mass, as in our case, the necessary investigations have been primarily assumed to be malignant. A case with breast and lung sarcoidosis presented here with review of literature.

Key words: Breast sarcoidosis, lung sarcoidosis, granulomatous inflammation.
'Gülhane Askeri Tıp Fakültesi, Göğüs Hastalıkları Anabilim Dalı, Ankara

${ }^{2}$ Gülhane Askeri Tıp Fakültesi, İmmünoloji Bilim Dalı, Ankara ${ }^{3}$ Gülhane Askeri Tıp Fakültesi, Patoloji Anabilim Dalı, Ankara ${ }^{4}$ Gülhane Askeri Tıp Fakültesi, Romatoloji Bilim Dalı, Ankara

${ }^{5}$ Gülhane Askeri Tıp Fakültesi, Radyoloji Anabilim Dalı, Ankara
'Department of Pulmonary Disease, Gülhane Military Medical Faculty, Ankara, Turkey

${ }^{2}$ Department of Immunology, Gülhane Military Medical Faculty, Ankara, Turkey

${ }^{3}$ Department of Pathology, Gülhane Military Medical Faculty, Ankara, Turkey

${ }^{4}$ Department of Romatology, Gülhane Military Medical Faculty, Ankara, Turkey

${ }^{5}$ Department of Radiology, Gülhane Military Medical Faculty, Ankara, Turkey

Submitted (Başvuru tarihi): 17.06.2013 Accepted (Kabul tarihi): 14.08.2013

Correspondence (iletişim): Cantürk Taşçı, Gülhane Askeri Tıp Fakültesi, Göğüs Hastalıkları Anabilim Dalı, Ankara e-mail: ctasci@gata.edu.tr 
Sarkoidoz etyolojisi bilinmeyen, kronik, multisistemik, her organ ve dokuyu tutabilen granülamatöz bir hastalıktır (1) Kesin tanı için klinik ve radyolojik bulgular ile birlikte biyopsilerle alınan örneklerde kazeifikasyon göstermeyen granülomları patolojik olarak göstermek ve bu lezyona sebep olabilecek diğer enfeksiyon hastalıklarını, otoimmün bozuklukları (Wegener granülamatozis vb), neoplazmları, ilaç reaksiyonlarını, hipersensivite pnömonisini, mesleksel ve çevresel maruziyete bağlı hastalıkları dışlamak gerekir (2). Akciğeri ve hiler lenf nodlarını daha sık olmakla birlikte deri, dalak, karaciğer, sinir sistemi, lökomotor sistem ve gözleri de tutabilir (3). Olgulardaki akciğer tutulumu \%90'dan fazla iken (4), akciğer dışı tutulum \%10 ila \%40 arasında görülmüştür (5). Kadınlarda genellikle üçüncü ve dördüncü dekatta görülür. Meme tutulumu \%1'den az olup, oldukça nadir görülmekle birlikte, ilk bulgu olarak da karşımıza çıkabilir (6).

Meme kanseri ve meme sarkoidozu farklı hastalıklar olmakla birlikte birbirini taklit edebilir, birbirini maskeleyebilir veya birlikte olabilirler. Memedeki lezyonlarla birlikte mediastinal lenfadenopatiler, akciğer parankim bulguları metastaz yapmış meme kanserini akla getirebilir.

Biz de öncelikle meme kanseri sanılan ancak yapılan tetkikler ile granulamatöz mastit ön tanısı konulan, tetkiklerin detaylandırılması ile akciğer ve meme sarkoidozu tanısı kesinleştirilen olgumuzu, literatürde birlikteliğinin nadir olması nedeni ile sunduk.

\section{OLGU}

Kırk bir yaşında kadın hasta, ev hanımı ve Ankara'da yaşıyor. 20 paket/yıl sigara hikâyesi dışında öz ve soy geçmişi özellik arz etmiyordu. Illaç kullanımı olmayan hasta, sol memesinde kendisinin tespit ettiği ele gelen kitle nedeni ile Genel Cerrahi polikliniğine başvurmuştu. Mamografi ve meme ultrasonografi bulguları ve hastanın yaşı ile birlikte değerlendirildiğinde öncelikle malign bir etyoloji düşünülerek cerrahi işlem uygulandı. Cerrahi eksizyon ile $6 \times 4 \times 3,5 \mathrm{~cm}$ ebatlarında yağdan zengin, kesit yüzeylerinde düzensiz gri-beyaz renkli milimetrik nodüllerin bulunduğu kitle çıkarıldı. Kitlenin patolojik incelemesi sonucunda "granulamatöz mastit ve aktif-kronik inflamasyon bulguları, kazeifikasyon saptanmamıştır" şeklinde raporlandı (Şekil 1). Bu tanı ile hastadan Romatoloji konsültasyonu alındı. İdiopatik granülamatöz mastit tanısı konmadan önce göğüs hastalıkları konsültasyonu alınan hastaya bilgisayarlı toraks tomografisi çekildi ve mediastinal lenfadenopati görüldü (Şekil 2). Balgam ARB tetkikleri üç kez negatif olarak geldi. Serum ACE (anjiotensin dönüş̧ürücü enzim) seviyesi normalin 3 katı yüksek olarak ölçüldü. Yapılan PPD testinin 0 (sıfır) mm olması üzerine akciğer ve meme bulguları birleștirildiğinde öncelikle sarkoidoz olabileceği düşünülerek bronkoskopi önerildi. Ancak hastanın işlemi kabul etmemesi üzerine, akciğer ve meme sarkoidozu tanısı ile tekrar romatoloji konsültasyonu alınan hastaya immünsüpresif tedavi (prednizolon ve azotiopürin) başlandı. Tedavisinin alııncı ayında kontrol meme ultrasonografisi ve Toraks BT (Şekil 3) çekildi ve herhangi bir patoloji saptanmadı. Hasta ilaçsız takip altına alındı.

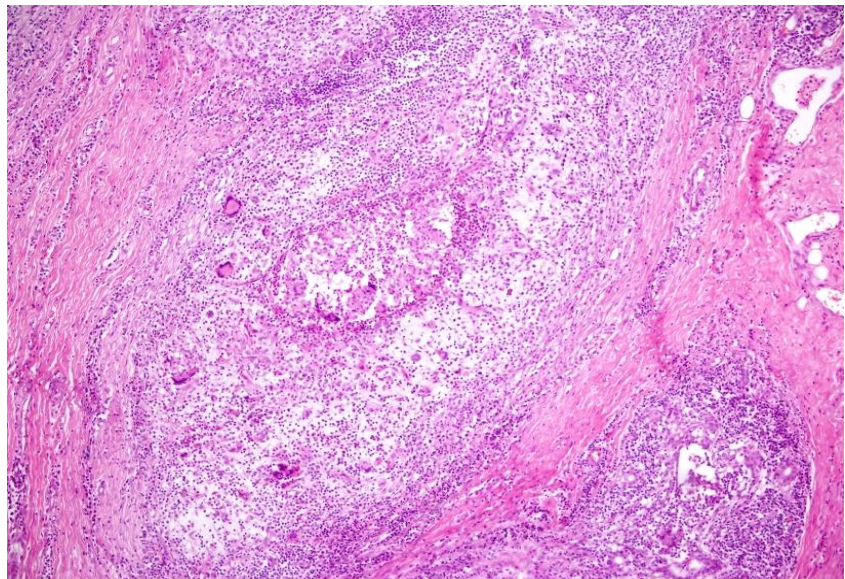

Şekil 1: Dev hücreleri de içeren duktus merkezli inflamatuar reaksiyon, non-kazeifiye granülamatöz inflamasyon (HEx 100).

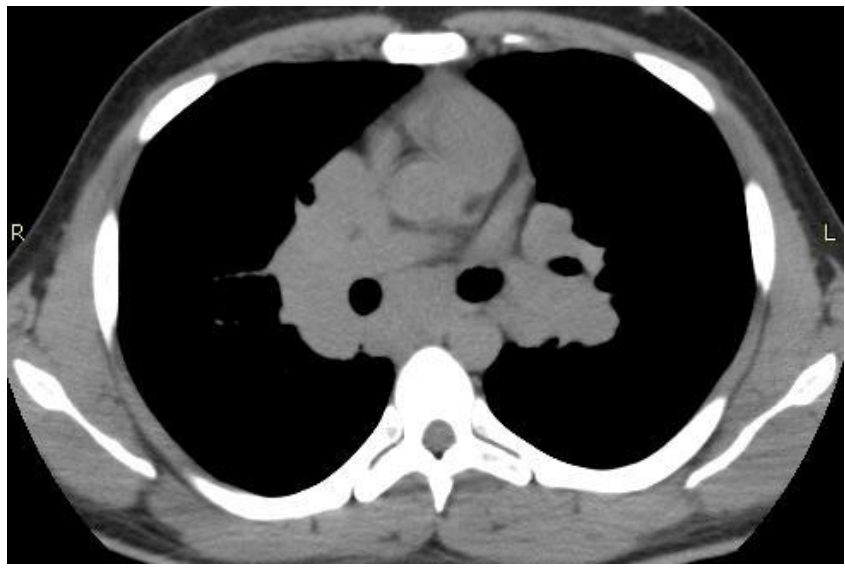

Şekil 2: Patolojik boyutta yaygın mediastinal lenfadenopati.

\section{TARTIŞMA}

Sarkoidoz etyolojisi bilinmeyen, her organ ve dokuyu tutabilen, akciğer tutulumu \%90'dan fazla, akciğer dışı tutulumu ise \%10-40 arası değişen kronik granülamatöz bir hastalıktır $(1,4)$. Meme tutulumu \% 1'den az olup bizim olgumuzda olduğu gibi ilk bulgu olarak karşımıza çıkabilir.

Göçmen ve ark.'nın (7) olgusu ile birlikte 6 olgu bilateral meme sarkoidozu olarak tespit edilmiştir. Literatürde bizim olgumuz gibi çoğunlukla tek taraflı tutulum görülmüştür. 


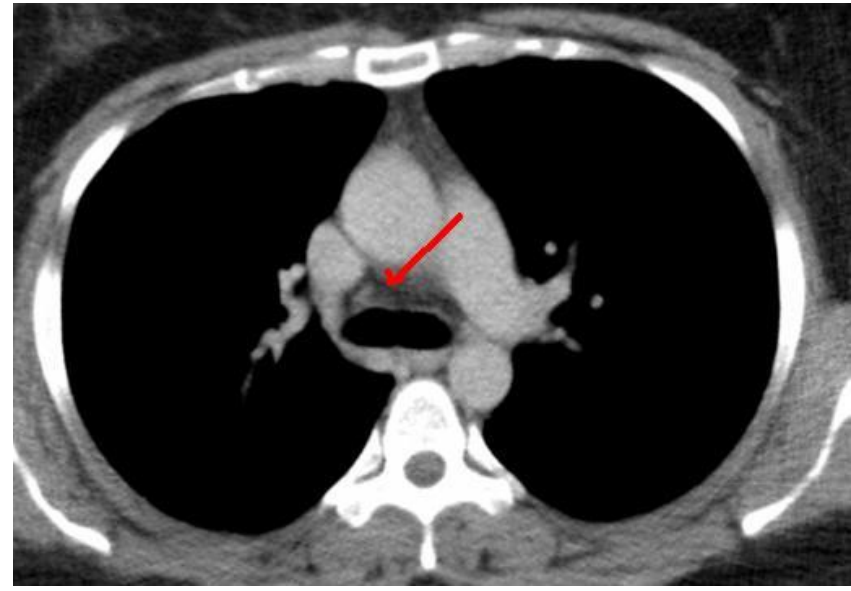

Şekil 3: Prekarinal patolojik boyutta olmayan mediastinal lenfadenopati.

Meme sarkoidozu, meme kanserini taklit edebilir, maskeleyebilir veya her iki hastalık birlikte olabilir. Hastaya teşhis konurken özellikle soy geçmiş ve özgeçmişi dikkatli irdeleyen anamnez ile fizik muayene çok iyi değerlendirilmeli, mamografi ve meme ultrasonografisi ve şüpheli lezyonlarda biyopsi mutlaka yapılmalıdır. Biyopsi sonucu saptanan nonkazeifiye granülamatöz lezyonlar, diğer etyolojiler ve hastalıklar dışlandıktan sonra immünsüpresif tedavi verilerek takip edilmelidir.

Fiorruci ve ark.'nın (8) rapor ettiği olguda, yaklaşık 30 yıl önce fibrokistik meme hastalı̆ı̆ tespit edilen ve düzenli takip yapılmayan hasta, artralji, fotofobi, konjuktivit ve üveit belirti ve bulguları nedeni ile sistemik bir hastalık araştırlırken, ACE, CA 15-3 yüksekliği ve radyolojik incelemelerde bilateral hiler lenfadenopati ve memedeki kitle ile birlikte, eski meme hastalığı da düşünülüp meme kanserinden şüphelenmişlerdir. Biyopsi sonrası sarkoidoz ile uyumlu granülomlar tespit edip steroid tedavisi başladıkları hastada, hiler lenfadenopatinin gerilediğini ve 20 aylık takipte meme lezyonunun nüksünü görmediklerini rapor etmişlerdir.

Bizim olgumuzda olduğu gibi, 1921-1997 yılları arası tespit edilen histolojik olarak kanıtlanmıs 35 meme sarkoidozlu hastanın 7 (\%20) tanesi, sistemik sarkoidoz belirtisi olmadan, ilk olarak memede kitle ile prezente olmuştur $(9,10)$.

Başka bir çalışmada, sarkoidozu ve memede kitlesi olan 629 hastaya yapılan meme biyopsisi sonucunda 6 hastada meme sarkoidozu tespit edilmiştir (11).

Sistemik sarkoidoz nedeni ile takip edilen hastada memede kitle tespit edildiğinde, sarkoidozun meme bulgusu olarak düşünülmemeli ve mutlaka biyopsi yapılmalıdır.

Takahashi ve ark.'nın (3) bildirdiği meme sarkoidozlu hasta, bizim olgumuzda olduğu gibi ailesinde ve kendisinde meme ve akciğer hastalığı öyküsü olmayan ve yapı- lan meme biyopsisi sonrası patolojik olarak meme sarkoidozu saptanan ve sonrasında çekilen akciğer grafisi ve bilgisayarlı toraks tomografisinde bilateral hiler lenfadenopati görülen bir olgudur. Bizim olgumuzdan farklı olarak bu hastada akciğer tutulumu görülmemiş̧ir (3). Takahashi bu olgusu için literatürü taradığında 29 meme sarkoidozlu hastanın 3'ünde bilateral tutulum, 5 hastada malign meme tümörü, 4 hastada fibrokist, fibroadenom gibi benign meme tümörü olduğunu rapor etmiştir.

Harris ve ark. (5) 53 yaşında memede ağrı, huzursuzluk hissi ile başvuran bir hastada yapılan tetkikler sonrası izole meme sarkoidozu tespit etmişlerdir. Nicholson ve ark. (12) akciğer ve hipofiz sarkoidozu nedeni ile remisyonda takip ettikleri hastada, mamografi kontrolünde her iki memede kitle tespit etmişler ve yaptıkları biyopsi sonrası meme sarkoidozu teşhisi koymuşlardır. Hermann ve ark (13), sarkoidoz, kronik öksürük ve hipertansiyon nedeni ile takip ettikleri 41 yaşındaki hastada herhangi bir şikâyeti olmaksızın yapılan rutin mamografide memede kitle tespit etmişler ve yapılan biyopsi sonucu meme sarkoidozu tanısı koymuşlardır. Andrew ve ark. (14) 14 yaşından beri sarkoidozis nedeni ile takip edilen hastada, 55 yaşında mamografide mikrokalsifikasyon gösteren 6 milimetrelik yuvarlak opasite tespit etmişler ve yapılan biyopsi sonucu intra mammarian lenf nodu sarkoidozu tanısı koymuşlardır.

Ataergin ve ark. (15), 12 yıl önce meme kanseri ile 6 kür kemoterapi alan ve tam remisyonda takip eden hastanın kontrol tomografisinde sağ tarafta minimal plevral efüzyon tespit etmişlerdir. Yapılan sitolojik incelemede malignite açısından negatif, CA 15-3 seviyesi hafif artmış bulunmuştur. On iki yıl önce meme kanseri düşünülerek hastaya paklitaxel ve farmarubisin tedavisi başlanmış ve kontrol tomografisinde 4 ay sonra sol akciğerde $1 \mathrm{~cm}$ ebadında nodül ve $0,8 \mathrm{~cm}$ çapında sağ aksiller lenf nodu tespit etmişlerdir. PET tetkikinde sol akciğerde hafif metabolik aktivite, sağ aksiller lenf nodlarında yüksek metabollik aktivite saptanmış ve hasta ikna edildikten sonra lenf nodu ve endobronşial biyopsiler sonucunda sarkoidoz tanısı konmuş ve kortikosteroid tedavisi sonrası hastanın bulguları gerilemiştir.

Sonuç olarak, sarkoidozda meme tutulumu nadir de olsa, özellikle memedeki, akciğerdeki veya lenf nodundaki herhangi bir şüpheli lezyona mutlaka ince iğne veya eksizyonel biyopsi yapılmalıdır. Hasta klinik, radyolojik ve patolojik bulgular birlikte değerlendirilip uygun tedavi ve takip planlanmalıdır. 


\section{ÇIKAR ÇATIŞMASI}

Bu makalede herhangi bir çıkar çatışması bildirilmemiştir.

\section{YAZAR KATKILARI}

Fikir - C.T., S.Y., A.G., B.K., E.T., H.B., S.Y.; Tasarım ve Dizayn - C.T., S.Y., A.G., B.K., E.T., H.B., S.Y.; Denetleme - C.T., S.Y., A.G., B.K., E.T., H.B., S.Y.; Kaynaklar S.Y.,B.K.; Malzemeler - B.K., A.G.; Veri Toplama ve/veya Issleme - S.Y., B.K.; Analiz ve/veya Yorum - S.Y., S.Y.; Literatür Taraması - C.T., A.G.; Yazıyı Yazan - C.T., S.Y.; Eleştirel Inceleme - E.T., H.B.

\section{KAYNAKLAR}

1. Wu JJ, Schiff KR. Sarcoidosis. Am Fam Physician 2004; 70:312-22.

2. Judson MA. Sarcoidosis: clinical presentation, diagnosis, and approach to treatment. Am J Med Sci 2008; 335:26-33. [CrossRef]

3. Takahashi R, Shibuya Y, Shijubo N, Asaishi K, Abe S. Mammary involvement in a patient with sarcoidosis. Intern Med 2001; 40:769-71. [CrossRef]

4. Mihailovic-Vucinic $V$, Jovanovic D. Pulmonary sarcoidosis. Clin Chest Med 2008; 29:459-73. [CrossRef]

5. Harris KP, Faliakou EC, Exon DJ, Nasiri N, Gui GP. Isolated sarcoidosis of the breast. J R Soc Med 2000; 93:196-7.

6. Sabate JM, Clotet M, Gomez A, De Las Heras P, Torrubia S, Salinas T. Radiologic evaluation of uncommon inflammatory and reactive breast disorders. Radiographics $2005 ; 25: 411-24$.

7. Göçmen H, Coşkun F, Balaban Adım Ş, Uzalsan E, Gözü E. Meme sarkoidozu. Trakya Univ Tip Fak Derg 2009; 26:70-73.
8. Fiorucci F, Conti V, Lucantoni G, Patrizi A, Fiorucci C, Giannunzio $G$, et al. Sarcoidosis of the breast: a rare case report and a review. Eur Rev Med Pharmacol Sci 2006; 10:47-50.

9. Ishimaru K, Isomoto I, Okimoto T, Itoyanagi A, Uetani M. Sarcoidosis of the breast. Eur Radiol 2002; 12(Suppl 3):S105-8.

10. Ojeda H, Sardi A, Totoonchie A. Sarcoidosis of the breast: implications for the general surgeon. Am Surg 2000; 66:1144-8.

11. Mona E, Pascal C, Charley H, Françoise B, Véronique B, Marie-Madeleine P. Quiz case. Breast sarcoidosis presenting as a metastatic breast cancer. Eur J Radiol 2005; 54:2-5.

12. Nicholson BT, Mills SE. Sarcoidosis of the breast: An unusual presentation of a systemic disease. Breast J 2007; 13:99-100. [CrossRef]

13. Hermann G, Nagi C, Mester J, Tierstein A. Unusual presentation of sarcoidosis of the breast. $\mathrm{Br} J$ Radiol 2008; $81:$ e231-3. [CrossRef]

14. Andrews DA, Michell MJ, Humphreys S, Roberts JV. An unusual cause of microcalcification: intramammary lymph node sarcoidosis. Breast 1998; 7:283-5. [CrossRef]

15. Ataergin S, Arslan N, Ozet A, Ozguven MA. Abnormal 18F-FDG uptake detected with positron emission tomography in a patient with breast cancer: a case of sarcoidosis and review of the literature. Case Rep Med 2009; 2009:785047. [CrossRef] 